\title{
KONTEKSTULISASI DAN REPOSISI FUNGSI WAKAF DALAM UPAYA MENINGKATKAN KESEJAHTERAAN UMAT
}

\author{
Moh. Subhan \\ STAI Miftahul Ulum Pamekasan \\ e-mail: orsatpmk@gmail.com
}

\begin{abstract}
The discourse on waqf recently appears the back to the surface. It not only discusses about the opinion of the figh scholars who have no uniform about understanding and nature waqf itself, but also to reform and optimize waqf in order to do more, namely to superintend the social problems of society, related to the prosperity of the economy of the people. Therefore, contextualization and repositioning of waqf institutions becomes a necessiry for immediate implementation. The function and role of waqf is very large in supporting the development and progress of the muslims. Therefore the management of waqf must be able to be optimized. Tragically the management of waqf in Indonesia is still not maximized, so there are some waqf property abandoned in its management, some even missing. This is due to the waqf management still uses traditional-consumptive management pattern. Efforts to develop waqf to be productive and productive, there are four things to note; Institutional aspect, accounting aspect, auditing aspect and aspect of nadhir. If these four aspects can be met, then the utilization of waqf will be more efficient. There are several forms of models that can be run by the manager of waqf, such as by holding Sharia banks as a partner with schema of muräbahah, istisnā', ijärah muntahiyah bi altamlik (financial leasing with purchase option), muzāra'ah, qard al-hasan, mushārakah (partnership) and muḍārabah muqayyadah.
\end{abstract}

Keywords: Contextualization, Repositioning of Waqf, Prosperity of the People

\section{Pendahuluan}

Wakaf adalah instrumen ekonomi Islam yang unik dan mendasarkan fungsinya pada unsur kebajikan (tabarru'), kebaikan (iḥsān) dan persaudaraan (ukhuwwah). Ciri utama wakaf adalah ketika seseorang menjadikan hartanya untuk wakaf maka terjadilah pergeseran kepemilikan pribadi menuju kepemilikan public/Allah SWT yang diharapkan dapat memberikan manfaat secara kontinuitas. Melalui wakaf diharapkan akan terjadi proses distribusi manfaat bagi masyarakat secara lebih luas, dari manfaat pribadi (private benefit) menuju manfaat masyarakat (social benefit). Wakaf merupakan salah satu intstrumen ekonomi umat Islam yang eksistensinya sudah ada semenjak awal kedatangan Islam. Hal ini terbukti dalam perjalanan sejarah bahwa wakaf menjadi salah satu penyokong kegiatankegiatan pemerintahan Islam pada masa itu. Banyak lembaga-lembaga pendidikan seperti, Universitas al-Azhar di Mesir, Universitas Zaituniyyah di Tunis, Universitas Nidhamiyah di Baghdad, mampu bertahan berabad-abad lamanya dan selama ratusan tahun mampu memberikan beasiswa kepada jutaan mahasiswa di seluruh dunia. Bahkan di Spanyol pada masa pemerintahan Turki Utsmani, fasilitas rumah sakit yang melayani pasien baik muslim maupun non muslim, juga berasal dari pengelolaan aset wakaf. ${ }^{1}$

\footnotetext{
${ }^{1}$ MA Manan, Sertifikat Wakaf Tunai, Sebuah Inovasi Instrumen Keuangan Islam (Jakarta: Ciber-PKTTI-UI,
} 
Sementara itu, fenomena pelaksanaan dan pengelolaan aset wakaf yang terjadi di Indonesia masih banyak dilakukan secara tradisional atau mendasarkan pada rasa saling percaya, sehingga proses perwakafan cukup diikrarkan bi al-lisān. Praktek wakaf seperti ini dapat menjadikan barang yang diwakafkan tidak memiliki bukti legal (sertifikat wakaf), karena tidak tercatat sebagai harta wakaf, sehingga apabila di kemudian hari terjadi permasalahan terhadap harta wakaf tersebut, penyelesaiannya akan menemui kesulitan, khususnya dalam hal pembuktian. Sedangkan dalam pengelolaan, di mana wakaf dianggap kurang berperan dalam ranah ekonomi umat disebabkan karena masih terbatas dan minimnya sumber daya pengelola wakaf, sehingga pengelolaan wakaf masih menggunakan pola manajemen tradisional-konsumtif. Padahal, di samping berdimensi ibadah, kegiatan wakaf juga bernilai ekonomis (economic values). Dimensi ekonomi kegiatan wakaf masih kurang dipahami oleh sebagian besar masyarakat Indonesia, sehingga manfaat ekonominya kurang membawa dampak dalam meningkatkan kesejahteraan masyarakat itu sendiri, bahkan beberapa aset wakaf banyak yang terbengkalai tidak terurus.

Berdasarkan pada uraian di atas, jelas bahwa wakaf menjadi salah satu instrumen penting dalam pengembangan dan peningkatan ekonomi umat. Oleh karena itu, sudah selayaknya umat Islam secara umum dan umat Islam di Indonesia secara khusus, merekonstruski sistem manajemen pengelolaan wakaf, agar harta wakaf dapat memberi manfaat secara signifikan dalam meningkatkan kesejahteraan umat Islam.

Harta wakaf bukan hanya berkisar pada harta tetap (fixed asset), melainkan juga berupa barang-barang tidak tetap/bergerak, seperti hewan, buku, dan sebagainya, bahkan Imam azZuhri $^{2}$ memfatwakan, diperbolehkannya wakaf uang berupa dinar dan dirham untuk pembangunan sarana dakwah, sosial dan pendidikan umat Islam. Wahbah az-Zuhaili juga mengungkapkan bahwa Mazhab Hanafi membolehkan wakaf tunai atas dasar istiḥsān bi al'urf, karena sudah banyak masyarakat yang melakukannya. Mazhab Hanafi berpendapat bahwa hukum wakaf uang yang ditetapkan berdasarkan 'urf (adat kebiasaan) mempunyai kekuatan yang sama dengan hukum yang ditetapkan berdasarkan nash (teks). Sementara di Indonesia sendiri wakaf uang (cash wakaf/waqf al-nuqūd) mendapat legitimasi dari pemerintah berdasarkan fatwa Majelis Ulama Indonesia (MUI). ${ }^{3}$

Peran dan fungsi wakaf yang demikian penting, perlu kiranya diadakan kajian ulang, analisis dan strategi pengelolaan dalam rangka pengembangan dan optimalisasi wakaf secara berkesinambungan agar harta wakaf dapat berdaya guna dalam rangka pemberdayaan ekonomi umat. Namun untuk melakukan optimalisasi fungsi wakaf dan pengembangannya, harus tetap berpedoman pada norma-norma hukum baik yang berasal dari kitab-kitab fiqh

2001), 12 .

2 Ibn Shihāb (51-124 H/ 671-741 M) lengkapnya Abu Bakar Muhammad ibn Muslim ibn 'Ubaidillah ibn 'Abdillah ibn Shihāb ibn 'Abdillah ibn al-Ḥārith ibn Zuhrah adalah salah satu ulama ahli hadits terbesar yang juga termasuk shighār al-tābi'in (tabi'in junior). Ia adalah orang pertama yang membukukan ilmu hadis atas perintah Khalifah Umar ibn Abdul Aziz.

${ }^{3}$ Fatwa MUI 11 Mei 2002, berbunyi: 1) Wakaf uang (cash wakaf/ waqf al-nuqud) adalah wakaf yang dilakukan seseorang, kelompok orang, lembaga atau badan hukum dalam bentuk uang tunai. 2) Termasuk ke dalam pengertian uang adalah surat-surat berharga. 3) Waqaf uang hukumnya jawāz (boleh), 4) Wakaf uang hanya boleh disalurkan dan digunakan untuk hal-hal yang dibolehkan secara syar'i. Nilai pokok wakaf uang harus dijamin kelestariannya, tidak boleh dijual, dihibahkan dan atau diwariskan. 
maupun undang-undang negara, agar dalam optimalisasi dan pengembangannya tidak menyalahi aturan.

\section{Pengertian dan Landasan Hukum Wakaf}

Wakaf berasal dari bahasa Arab, waqf yang berarti al-ḥabs, yaitu menghentikan atau menahan. ${ }^{4}$ Wakaf merupakan kata berbentuk masdar (gerund) dari ungkapan waqf al-shay' yang pada dasarnya berarti menahan sesuatu. Dengan demikian, pengertian wakaf secara bahasa adalah menyerahkan sesuatu untuk ditahan. Sedangkan makna wakaf dalam term terminologi masih terjadi perselisihan di antara para ulama, sebagaimana terdapat dalam kitab-kitab fiqh. Perbedaan pendapat tersebut membawa implikasi terhadap status hukum yang ditimbulkan. Definisi wakaf menurut para ahli fiqh adalah sebagai berikut.

Pertama, Ulama Hanafiyah mengartikan wakaf sebagai menahan materi benda (al- 'ain) milik waqïf dan menyedekahkan atau mewakafkan manfaatnya kepada siapapun yang diinginkan untuk tujuan kebajikan. ${ }^{5}$ Dari definisi tersebut dapat dipahami, bahwa kedudukan harta wakaf masih tetap tertahan atau terhenti di tangan waqīf itu sendiri. Dengan artian, harta yang diwakafkan masih menjadi milik waqiff, karena wakaf hanya terjadi atas manfaat harta tersebut, bukan termasuk aset hartanya.

Kedua, Ulama Malikiyah berpendapat bahwa wakaf adalah menjadikan manfaat suatu benda yang dimiliki (walaupun kepemilikannya dengan cara sewa) untuk diberikan kepada orang yang berhak dengan satu akad (șighah) dalam jangka waktu tertentu sesuai dengan keinginan waqif. ${ }^{6}$ Berkaitan dengan wakaf yang berlaku sementara tersebut, saat ini di Eropa dan Amerika sebagian penganut Islam sudah biasa melaksanakannya, terutama yang terdapat mahasiswa muslim. Mereka banyak menggunakan masjid digunakan untuk shalat dan berkumpul yang disewa dari orang-orang non muslim. Mereka pindah menggunakan masjid, setelah sebulan atau setahun ke tempat lain dengan cara menyewa juga. Sehingga konsep dari ulama saat ini memungkinkan untuk dikembangkan, mengingat perkembangan industri yang pesat mengakibatkan tanah menjadi sulit dan harganya menjadi mahal, terutama di beberapa daerah yang menjadi pusat industri. Misalnya pada suatu daerah yang menjadi pusat industri belum ada masjid jami, sebelum mendapatkan tanah wakaf yang strategis, maka seseorang atau beberapa orang mengontrak sebidang tanah dengan bangunannya atau satu lantai dari bangunan bertingkat selama satu tahun atau selama masa kontrak, kemudian ia mewakafkan selama masa kontrak ini untuk kegiatan ibadah kaum muslimin.

Ketiga, Ulama Syafi'iyah mengartikan wakaf dengan menahan harta yang bisa memberi manfaat serta kekal materi bendanya (al- 'ain) dengan cara memutuskan hak pengelolaan yang dimiliki oleh waqïf untuk diserahkan kepada nadir yang dibolehkan oleh syariah. ${ }^{7}$ Golongan ini mensyaratkan harta yang diwakafkan harus harta yang kekal materi bendanya (al-'ain), dalam arti harta yang tidak mudah rusak atau musnah serta dapat diambil manfaatnya secara terus-terusan. Konsekwensi dari definisi tersebut adalah harta yang telah diwakafkan

\footnotetext{
${ }^{4}$ Ibn Manzūr, Lisān al- 'Arab, jilid 11 (Kairo: al-Dār al-Mișriyyah li al-Ta' lif wa al-Tarjamah, 1954), 276.

${ }^{5}$ al-Imām Kamāl al-Dīn Ibn 'Abd al-Rashīid al-Sirāsi Ibn al-Humam, Sharḥ Fatḥ al-Qādir, jld. 6 (Beirut: Dār alKutub al-'Ilmiyyah, 1970), 203.

${ }^{6}$ Shams al-Dīn al-Shaikh Muḥammad al-Dāsūqii, Hị̄shiyah al-Dāsūqī 'alā al-Sharḥ al-Kabīr, juz 2 (Beirut: Dār al-Fikr, tt.), 187.

${ }^{7}$ Muhammad al-Khatīb al-Sharbini, Mughnī al-Muḥtāj, juz 2 (Kairo: Mușṭafā al-Bāb al-Ḥalabi, 1958), 376.
} 
statusnya lepas dari kepemilikan orang yang berwakaf (waqiff), dan waqif tidak boleh melakukan apa saja terhadap harta yang diwakafkan tersebut, seperti menarik kembali, menjual atau menukarnya. Jika waqîf wafat, harta yang diwakafkan tersebut tidak dapat diwarisi oleh ahli warisnya.

Keempat, Hanabilah mendefinisikan wakaf, menahan kebebasan pemilik harta dalam membelanjakan hartanya yang bermanfaat dengan tetapnya dzat benda serta memutus semua hak wewenang atas harta itu, sedang manfaat benda dipergunakan pada jalan kebaikan untuk mendekatkan diri kepada Allah SWT. ${ }^{8}$

Sedangkan dalam konteks perundangan di Indonesia, wakaf dimaknai secara spesifik dengan menemukan titik temu dari berbagai pendapat ulama tersebut. Hal ini dapat terlihat dalam rumusan pengertian wakaf dalam Undang-Undang Nomor 41 Tahun 2004, wakaf adalah perbuatan hukum waqif untuk memisahkan dan/atau menyerahkan sebagian harta benda miliknya untuk dimanfaatkan selamanya atau untuk jangka waktu tertentu sesuai dengan kepentingannya guna keperluan ibadah dan/atau kesejahteraan umum menurut syariah. ${ }^{9}$ Rumusan dalam UU wakaf tersebut, jelas sekali merangkum berbagai pendapat para ulama fiqh tersebut di atas tentang makna wakaf, sehingga makna wakaf dalam konteks Indonesia lebih luas dan lebih komplit.

Dari beberapa definisi wakaf tersebut, dapat disimpulkan bahwa wakaf bertujuan untuk memberikan manfaat atau faedah harta yang diwakafkan kepada orang yang berhak dan dipergunakan sesuai dengan ajaran syariah Islam. Hal ini sesuai dengan fungsi wakaf yang disebutkan pada pasal 5 UU No. 41 tahun 2004 yang menyatakan wakaf berfungsi untuk mewujudkan potensi dan manfaat ekonomis harta benda wakaf untuk kepentingan ibadah dan untuk memajukan kesejahteraan umum.

\section{Dasar Hukum Wakaf}

Secara umum, tidak terdapat ayat al-Quran yang menerangkan konsep wakaf secara konkrit. Wakaf termasuk infāq fí sabīl Allah, maka dasar yang digunakan para ulama dalam menerangkan konsep wakaf didasarkan pada keumuman ayat-ayat al-Quran yang menjelaskan tentang infäq fì sabìl Allah. Di antara ayat-ayat tersebut antara lain:

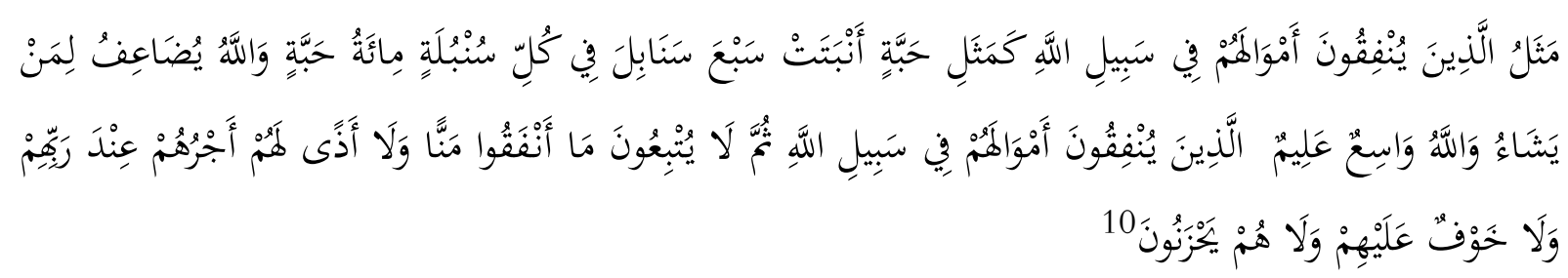

"Perumpamaan (nafkah yang dikeluarkan oleh) orang-orang yang menafkahkan hartanya di jalan Allah adalah serupa dengan sebutir benih yang menumbuhkan tujuh bulir, pada tiap-tiap bulir terdapat seratus biji. Allah melipat gandakan (ganjaran) bagi siapa yang Dia kehendaki. Dan Allah Maha Luas (karunia-Nya) lagi Maha Mengetahui.

\footnotetext{
${ }^{8}$ Sayyid Ali Fikri, al-Mu'āmalāt al-Mādiyah wa al-Adabiyah, Juz II (Mesir: Mușṭafā al-Bāb al-Halabi, 1938), 312.

${ }^{9}$ Undang-Undang Nomor 41 Tahun 2004 tentang Wakaf pasal 1 ayat 1.

${ }^{10}$ al-Quran: 2: 261-262.
} 
Orang-orang yang menafkahkan hartanya di jalan Allah, kemudian mereka tidak mengiringi apa yang dinafkahkannya itu dengan menyebut-nyebut pemberiannya dan dengan tidak menyakiti (perasaan si penerima), mereka memperoleh pahala di sisi Tuhan mereka. Tidak ada kekhawatiran terhadap mereka dan tidak (pula) mereka bersedih hati".

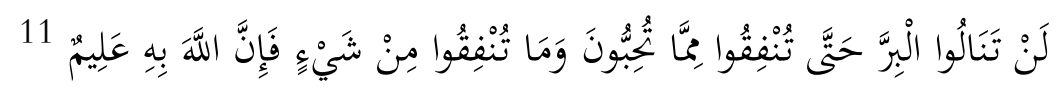

"Kamu sekali-kali tidak sampai kepada kebajikan (yang sempurna) sebelum kamu menafkahkan sebagian dari apa yang kamu cintai. Dan apa saja yang kamu nafkahkan, maka sesungguhnya Allah mengetahuinya".

Ayat-ayat tersebut di atas menjelaskan tentang anjuran untuk menginfakkan harta yang diperoleh untuk mendapatkan pahala dan kebaikan. Di samping itu, ayat 261 surat al-Baqarah telah menyebutkan pahala yang berlipat ganda yang akan diperoleh orang yang menginfakkan hartanya di jalan Allah.

Di antara hadits yang menjadi dasar dan dalil wakaf adalah hadits yang menceritakan tentang kisah Umar bin al-Khaththab ketika memperoleh tanah di Khaibar. Setelah ia meminta petunjuk Nabi tentang tanah tersebut, Nabi menganjurkan untuk menahan asal tanah dan menyedekahkan hasilnya, sebagaimana beberapa riwayat hadits di bawah ini.

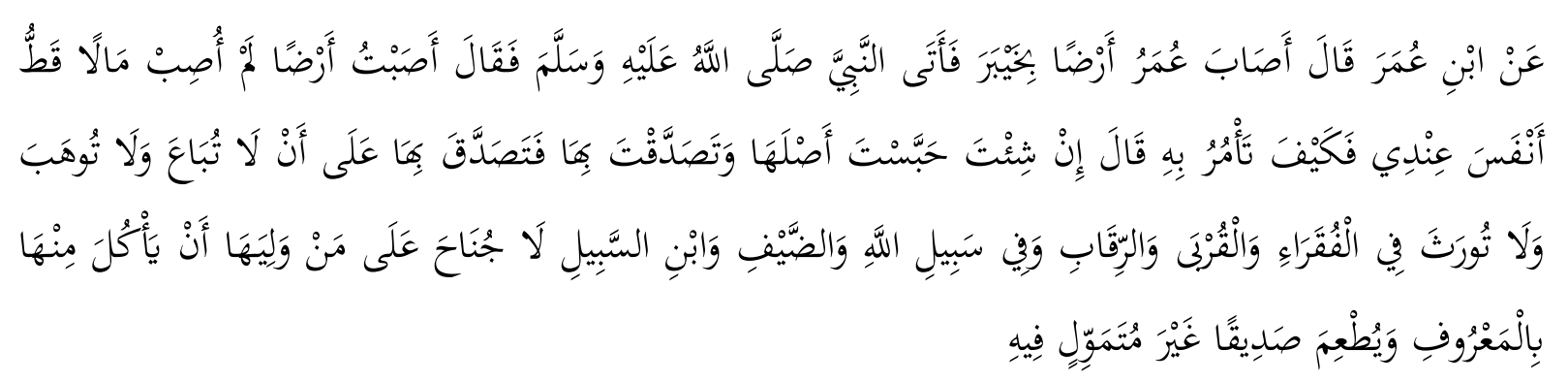

Dari Ibnu Umar berkata: "Umar telah mendapatkan lahan di Khaibar, kemudian ia datang kepada Nabi SAW dan berkata, "Aku telah mendapatkan lahan yang tidak ada harta sama sekali yang aku dapatkan yang lebih berharga bagi aku daripada lahan tersebut, maka apa yang anda perintahkan? Beliau bersabda: Apabila engkau menghendaki maka engkau dapat menahan pokoknya dan bersedekah dengannya. Maka ia pun bersedekah dengan syarat tidak dijual, tidak dihibahkan, tidak diwariskan untuk orang-orang fakir, kerabat rasul, hamba sahaya, di jalan Allah, tamu, dan ibn sabïl. Tidak mengapa bagi orang yang mengurusnya untuk makan darinya dengan cara yang baik, memberi makan teman tanpa mengembangkannya".

Dalam konteks ke-Indonesia-an, wakaf telah dipraktekkan oleh masyarakat muslim Indonesia sebelum kemerdekaan. Setelah kemerdekaan, pemerintah Indonesia pun telah menetapkan berbagai peraturan yang mengatur tentang wakaf, seperti UU No. 5 Tahun 1960 tentang Peraturan Dasar Pokok-pokok Agraria, PP No. 28 Tahun 1977 tentang Perwakafan

\footnotetext{
11 al-Quran: 3:92.
} 
Tanah Milik, Peraturan Menteri No. 1 Tahun 1978 tentang Peraturan Pelaksanaan PP No. 28 Tahun 1977. Tahun 2004 pemerintah mengeluarkan undang-undang khusus tentang perwakafan, yaitu Undang-Undang Nomor 41 tahun 2004 tentang Wakaf. Realisasi dan aplikasi dari undang-undang tersebut, pemerintah menetapkan Peraturan Pemerintah Nomor 42 tahun 2006 tentang Pelaksanaan Undang-undang Nomor 41 tahun 2004.

\section{Syarat dan Rukun Wakaf dalam Konteks Ke-Indonesiaan}

Wakaf dinyatakan sah apabila telah terpenuhi rukun dan syaratnya. Rukun wakaf versi fiqh ada 4 (empat), yaitu (1) waqïf (orang yang mewakafkan), (2) mauqüf 'alaih (pihak yang diserahi wakaf), (3) mauqüf (harta yang diwakafkan), (4) șighah atau iqrär (pernyataan atau ikrar waqïf sebagai suatu kehendak untuk mewakafkan). ${ }^{12}$

Sedangkan dalam UU No. 41 tahun 2004 pasal 6, sahnya wakaf jika telah memenuhi 6 unsur yaitu; (1) waqīf, (2) naḍir, (3) harta benda wakaf, (4) ikrar wakaf, (5) peruntukan harta benda wakaf dan (6) jangka waktu wakaf. ${ }^{13}$

Dalam konteks ke-Indonesia-an, waqïf meliputi perseorangan, organisasi, maupun badan hukum. Waqï perseorangan dapat melakukan wakaf apabila memenuhi persyaratan dewasa, berakal sehat, tidak terhalang melakukan perbuatan hukum, pemilik sah harta benda wakaf dan kemauan sendiri. ${ }^{14}$ Waqif organisasi dan badan hukum dapat melakukan wakaf apabila memenuhi ketentuan organisasi atau badan hukum untuk mewakafkan harta benda wakaf milik organisasi atau badan hukum sesuai dengan anggaran dasar organisasi atau badan hukum yang bersangkutan. ${ }^{15}$

Sedangkan nadir bisa dilakukan oleh perseorangan, organisasi, atau badan hukum. Syarat nadir perseorangan adalah warga negara Indonesia, beragama Islam dewasa, amanah, mampu secara jasmani dan rohani, dan tidak terhalang melakukan perbuatan hukum. Organisasi atau badan hukum yang bisa menjadi nadir harus memenuhi persyaratan, yaitu pengurus organisasi atau badan hukum yang bersangkutan memenuhi persyaratan nadir perseorangan sebagaimana tersebut di atas, organisasi atau badan hukum itu bergerak di bidang sosial, pendidikan, kemasyarakatan, dan atau keagamaan Islam, badan hukum itu dibentuk sesuai dengan peraturan perundang-undangan yang berlaku di Indonesia.

Syarat-syarat harta yang diwakafkan (al-mauqūf) harus memenuhi beberapa persyaratan, yaitu al-mauqüf harus barang yang berharga, al-mauqüf harus diketahui kadarnya, al-mauqüf dimiliki oleh waqïf secara sah, al-mauqüf harus berdiri sendiri, tidak melekat kepada harta lain (mufarradan). Harta benda wakaf bisa berbentuk benda tidak bergerak ataupun benda bergerak.

Syarat-syarat șighah berkaitan dengan ikrar wakaf, yaitu harus memuat nama dan identitas waqiff, nama dan identitas nadir, keterangan harta benda wakaf, dan peruntukan harta benda wakaf, serta jangka waktu wakaf. Pada prinsipnya, dalam rangka mencapai tujuan dan fungsi wakaf, harta benda wakaf hanya dapat diperuntukan bagi sarana dan kegiatan ibadah,

\footnotetext{
12 al-Sharbini, Mughnī al-Mụtāj, juz 2 (Kairo: Mușțafā al-Bāb al-Halabi, t.th), 376.

${ }^{13}$ Pasal 6 UU No. 41/2004 tentang Wakaf.

14 Muhammad ibn Abdillāh al-Kabisi, Ahkām al-Waqf fī al-Sharī'ah al-Islāmiyah, terj. Ahrul Sani Fathurrahman (Jakarta: Dompet Dhuafa', 2004), 217.

${ }^{15}$ UU Wakaf bagian keempat Pasal 7-8.
} 
sarana dan kegiatan pendidikan serta kesehatan, bantuan kepada fakir miskin, anak terlantar, yatim piatu, bea siswa, kemajuan dan peningkatan ekonomi umat dan atau kemajuan kesejahteraan umum lainnya yang tidak bertentangan dengan syariah dan peraturan perundang-undangan.

\section{Pengelolaan dan Manajemen Wakaf}

Wakaf di samping sebagai akad tabarru' yang berorientasi pada ibadah, di sisi lain wakaf juga sebagai economic corporation, dalam artian wakaf merupakan kegiatan yang mengandung unsur investasi masa depan bagi generasi yang akan datang baik berupa pelayanan maupun pemanfaatan hasilnya secara langsung. Investasi yang dimaksud berupa investasi yang kepemilikan dan tujuannya mampu menghasilkan keuntungan yang direncanakan secara profesional dan hasilnya disalurkan untuk kepentingan umat. Tetapi persoalannya, sampai saat ini pengelolaan dan manajemen wakaf di Indonesia masih kurang maksimal dan optimal, sehingga ada beberapa harta wakaf yang terlantar dalam pengelolaannya, bahkan ada yang hilang.

Berdasarkan kondisi riil di atas, kajian mengenai manajemen pengelolaan wakaf sangat penting. Kurang berperannya wakaf dalam memberdayakan ekonomi umat di Indonesia selama ini, di antaranya karena wakaf tidak dikelola secara produktif. Solusi dalam mengatasi masalah tersebut adalah wakaf harus dikelola secara produktif dengan menggunakan manajemen modern. Untuk mengelola wakaf secara produktif, ada beberapa hal yang perlu dilakukan sebelumnya. Selain memahami konsepsi fikih wakaf dan peraturan perundangundangan, nad̦ir harus profesional dalam mengembangkan harta yang dikelolanya, apalagi jika harta wakaf tersebut berupa uang. Di samping itu, untuk mengembangkan wakaf secara nasional, diperlukan badan khusus yang mengkoordinasi dan melakukan pembinaan terhadap naḍir, dalam hal ini di Indonesia sudah dibentuk BWI (Badan Wakaf Indonesia).

Terkait dengan pengelolaan wakaf secara produktif, ada beberapa hal yang harus diperhatikan, yaitu:

1. Aspek Kelembagaan Wakaf

Untuk mengelola benda-benda wakaf secara produktif, yang pertama harus dilakukan adalah perlunya pembentukan suatu badan atau lembaga yang khusus mengelola wakaf. Kelahiran Badan Wakaf Indonesia (BWI) merupakan perwujudan amanat yang digariskan dalam Undang-Undang Nomor 41 Tahun 2004 tentang wakaf. Kehadiran BWI, sebagaimana dalam Pasal 47 dalam melaksankan tugasnya bersifat bebas dari pengaruh kekuasaan, serta bertanggung jawab kepada masyarakat. ${ }^{16}$ BWI secara organisatoris bersifat independen, di mana pemerintah dalam hal ini sebagai fasilitator, regulator, motivator dan pengawasan.

BWI selain memiliki tugas-tugas konstitusi, ${ }^{17}$ juga memiliki tugas lain, yaitu: ${ }^{18}$

\footnotetext{
${ }^{16}$ Andri Soemita, Bank dan Lembaga Keuangan Syariah, cet ke-2 (Jakarta: Kencana, 2010), 445.

${ }^{17}$ Pasal 49 UU No. 41/2004 tentang Wakaf.

18 Pedoman Pengelolaan dan Pengembangan Wakaf oleh Depag RI Dirjend. Bimas Direktorat Pemberdayaan Wakaf tahun 2006, 105-106.
} 
a. Merumuskan kembali fikih wakaf baru di Indonesia, agar wakaf dapat dikelola lebih praktis, fleksibel dan modern tanpa kehilangan wataknya sebagai lembaga Islam yang kekal.

b. Membuat kebijakan dan strategi pengelolaan wakaf produktif, mensosialisasikan bolehnya wakaf benda-benda bergerak dan sertifikat tunai kepada masyarakat.

c. Menyusun dan mengusulkan kepada pemerintah regulasi bidang wakaf.

Ketiga tugas di atas tentu merupakan tugas yang berat bagi BWI, oleh karena itu personal yang duduk dalam lembaga tersebut harus benar-benar orang yang memiliki kemauan dan kemampuan dalam mengelola wakaf dan hal-hal yang terkait dengan wakaf.

2. Aspek Akuntansi

Akuntansi dapat dipahami sebagai kegiatan pencatatan kegiatan usaha bisnis, baik komersial ataupun bukan, untuk tujuan tertentu. ${ }^{19}$ Berdasarkan tujuan dasar dan pola operasi sebuah entitas, akuntansi dapat dipilah menjadi dua, yaitu ${ }^{20}$ pertama, akuntansi untuk organisasi yang bermotifkan mencari laba (profit oriented organization), ini biasanya diwakili oleh perusahaan-perusahaan komersial, baik yang bersifat menjual jasa, perdagangan, dan perusahaan manufaktur. Kedua, akuntansi untuk organisasi nirlaba (non-profit oriented organizaation), ini diwakili oleh organisasi pemerintahan di segala tingkatan (pusat, propinsi, kabupaten, dan seterusnya), lembaga pendidikan, organisasi massa dan sosial kemasyarakatan, termasuk organisasi dan badan hukum yang banyak mengelola kekayaan wakaf. Oleh karena itu, aspek akuntansi ini sangat dibutuhkan dalam pengelolaan wakaf secara produktif sehingga apa yang menjadi tujuan dari pemberdayaan benda wakaf tersebut tercapai sesuai dengan yang diharapkan. Di samping itu, harus memperhatikan apa yang menjadi tuntutan akuntansi yang dipandang lebih mendekati dengan prinsip syariah baik dari aspek tujuan dan aspek metode tekniknya.

3. Aspek Auditing

Auditing dalam bahasa Indonesia bermakna pemeriksaan, sedangkan secara harfiah dapat diartikan pihak tertentu melaporkan secara terbuka tugas yang diberikan kepadanya, dan pihak yang memberi amanah mendengarkan. Jadi, auditing merupakan manifestasi pertanggung jawaban pihak tertentu yang diberi amanah kepada pihak yang memberi amanah. ${ }^{21}$

Dalam konteks lembaga wakaf secara umum, auditing dibentuk dalam rangka untuk mengelola sejumlah kekayaan wakaf, agar manfaat wakaf benar-benar dapat dicapai secara maksimal, sehingga mampu meningkatkan kesejahteraan hidup umat secara umum, dan menolong mereka yang kurang mampu. ${ }^{22}$ Hal yang harus diperhatikan dalam proses auditing adalah, tidak melanggar asas-asas syariah.

Tujuan audit atas laporan keuangan yang dilakukan oleh auditor independen untuk menyatakan penilaian atas kewajaran yang menyangkut posisi keuangan, hasil usaha, dan arus kas yang sesuai dengan prinsip akuntansi. ${ }^{23}$ Auditing merupakan proses manajemen

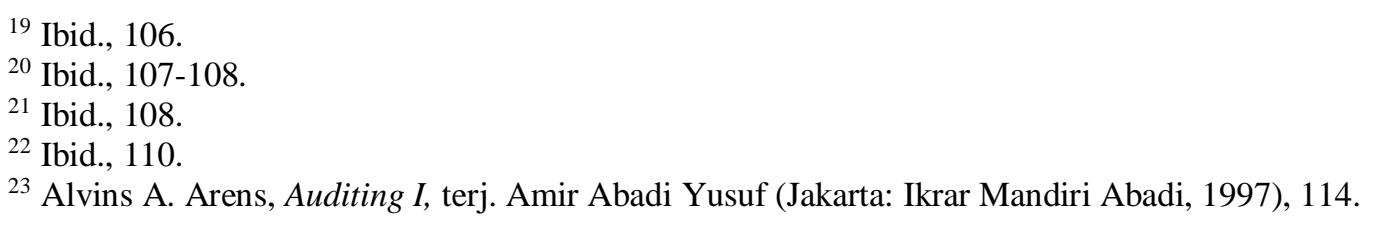


yang penting dan akan berimplikasi pada meningkatnya kepercayaan (trust) masyarakat. Dengan demikian, pengelolaan wakaf yang produktif memerlukan pengelolaan secara professional dengan melibatkan sistem manajemen modern.

4. Nadirir (pengelola wakaf)

Dalam terminologi fiqh, yang dimaksud dengan nadir adalah orang yang diserahi kekuasaan dan kewajiban untuk mengurus dan memelihara harta wakaf. ${ }^{24}$ Naḍir bisa berbentuk perorangan, organisasi dan badan hukum. Naḍir, baik berupa perorangan, organisasi atau berupa badan hukum, sebagai pemegang amanat untuk memelihara, mengurus dan mengelola harta wakaf, sudah sepantasnya mempunyai kewajibankewajiban yang harus dilaksanakannya, di samping juga mempunyai hak-hak yang mesti diterimanya atas tugas-tugasnya tersebut. ${ }^{25}$

Pada dasarnya siapapun dapat saja menjadi naḍir asalkan ia tidak terhalang melakukan tindakan hukum, akan tetapi karena fungsi naḍir sangat penting dalam perwakafan maka diberlakukan syarat-syarat naḍir. Para Imam mazhab sepakat bahwa nadir harus memenuhi syarat adil dan mampu. Para ulama berbeda pendapat mengenai ukuran adil. Jumhur ulama berpendapat bahwa yang dimaksud adil adalah mengerjakan yang diperintahkan dan menjauhi yang dilarang syariat. ${ }^{26}$ Sedangkan "mampu" menurut Ahmad Rofiq dalam bukunya Hukum Islam Di Indonesia adalah memiliki kreativitas dan profesionalitas (zara'iy). Hal ini didasarkan pada perbuatan Umar menunjuk Hafsah menjadi naḍir karena ia dianggap mempunyai kreativitas. ${ }^{27}$

Berfungsi atau tidaknya wakaf sangat tergantung pada kemampuan naḍir. Di berbagai negara yang wakafnya dapat berkembang dan berfungsi untuk memberdayakan ekonomi umat, sebab wakaf dikelola oleh nad̦ir yang profesional. Sedangkan di Indonesia, masih sedikit naḍir yang professional, atau dengan kata lain masih banyak naḍir yang tradisional, bahkan ada beberapa naḍir yang kurang memahami hukum wakaf, termasuk kurang memahami hak dan kewajibannya. Ketradisionalan naḍir ini dipengaruhi oleh beberapa hal, yaitu: ${ }^{28}$

a. Masih kuatnya paham mayoritas umat Islam yang masih stagnan terhadap persoalan wakaf, mereka lebih mementingan aspek keabadian benda wakaf dan mengesampingkan aspek kemanfatannya, sehingga banyak harta benda wakaf yang kurang memberi manfaat bagi masyarakat.

b. Rendahnya kualitas SDM naḍir wakaf.

c. Masih lemahnya kemauan para nad̦ir wakaf. Banyak nadir yang kurang memiliki semangat pemberdayaan harta wakaf untuk kesejahteraan umat.

\footnotetext{
${ }^{24}$ Ibn Shihāb al-Ramli, Nihāyah al-Muhtāj, Juz IV (Beirut: Da.r al-Kitāb al-Alamiyah, 1996), 610.

25 Pasal 11 UU No. 41/2004. Naḍir mempunyai tugas a). melakukan pengadministrasian harta benda wakaf; b). mengelola dan mengembangkan harta benda wakaf sesuai dengan tujuan, fungsi, dan peruntukannya; c). mengawasi dan melindungi harta benda wakaf; d). melaporkan pelaksanaan tugas kepada Badan Wakaf Indonesia. Lihat juga Pasal 12. Dalam melaksanakan tugas sebagaimana dimaksud dalam Pasal 11, naḍir dapat menerima imbalan dari hasil bersih atas pengelolaan dan pengembangan harta benda wakaf yang besarnya tidak melebihi $10 \%$ (sepuluh persen).

${ }^{26}$ Said Agil Husain Al-Munawar, Hukum Islam dan Pluralitas Sosial (Jakarta: Penamadani, 2004), 16.

${ }^{27}$ Ahmad Rofiq, Hukum Islam di Indonesia (Jakarta: PT Grafindo Persada, 1998), 499.

${ }^{28}$ Ahmad Djunaidi dan Thobieb al-Asyhar, Menuju Era Wakaf Produkti (t.t.p: t.p, 2007), 52.
} 
Di samping itu, dalam berbagai kasus ada sebagian nadir yang kurang memegang amanah, seperti melakukan penyimpangan dalam pengelolaan, kurang melindungi harta wakaf, dan kecurangan-kecurangan lain, sehingga memungkinkan wakaf tersebut berpindah tangan. Para naḍir ternyata tidak fokus dalam mengelola aset, mereka mayoritas bekerja sambilan dan tidak diberi upah (84\%), dan yang bekerja secara penuh dan terfokus ternyata amatlah minim (16\%). Selain itu, wakaf di Indonesia lebih banyak dikelola oleh perseorangan $(66 \%)$ alias tradisional, daripada organisasi professional (16\%) dan berbadan hukum $(18 \%){ }^{29}$

Oleh karena itu, agar naḍir dapat bekerja secara profesional dalam mengelola wakaf maka nadir harus memiliki berbagai kemampuan yang menunjang tugasnya sebagai naḍir, yakni: ${ }^{30}$

a. Memahami hukum wakaf dan peraturan perundang-undangan yang terkait dengan masalah perwakafan. Seorang nadir sudah seharusnya memahami dengan baik hukum wakaf dan peraturan perundang-undangan yang terkait dengan masalah perwakafan. Tanpa memahami hal-hal tersebut, maka naḍir tersebut tidak akan mampu mengelola wakaf dengan baik dan benar;

b. Memahami tentang ekonomi syariah dan instrumen keuangan syariah, karena wakaf merupakan salah satu lembaga ekonomi Islam yang sangat potensial untuk dikembangkan.

c. Mengelola keuangan secara profesional dan sesuai dengan prinsip-prinsip syariah, seperti melakukan investasi dana wakaf. Investasi ini dapat berupa investasi jangka pendek, menengah maupun jangka panjang;

d. Melakukan distribusi hasil investasi dana wakaf. Di samping mampu melakukan investasi, diharapkan naḍir juga mampu mendistribusikan hasil investasi dana wakaf kepada mauqüf 'alaih. Diharapkan pendistribusiannya tidak hanya bersifat konsumtif, tetapi dapat memberdayakan mauqüf 'alaih;

e. Mengelola dana wakaf secara transparan dan akuntabel.

Untuk mengembangkan SDM naçir tersebut diperlukan upaya pembinaan melalui: ${ }^{31}$

a. Pendidikan formal, yaitu melalui sekolah-sekolah umum, kejuruan, bahkan perguruan tinggi sekaligus. Salah satu perguruan tinggi yang mempunyai prodi wakaf adalah UIN Wali Songo Semarang.

b. Pendidikan non formal, yaitu melalui kursus-kursus atau pelatihan SDM kenaḍiran, baik yang terkait dengan manajerial organisasi, atau meningkatkan keterampilan dalam bidang profesi kenaḍiran.

c. Pendidikan informal, berupa latihan-latihan dan kaderisasi langsung di tempattempat pengelolaan benda wakaf.

\footnotetext{
${ }^{29}$ Najib dkk, Wakaf, Tuhan, dan Agenda Kemanusiaan (t.t.p: t.p, 2006), 119.

${ }^{30}$ Uswatun Hasanah, "Wakaf Produktif Untuk Kesejahteraan dalam Perspektif Hukum Islam di Indonesia (t.t.p: t.p, t.th), 28-29.

${ }^{31}$ Anonim, Paradigma Baru Wakaf di Indonesia (Jakarta: Direktorat Pemberdayaan Wakaf Departemen Agama RI, 2007), 118-122.
} 
d. Pembinaan mental. Spirit kerja harus terus-menerus dibina agar para naḍir bersemangat dalam melaksanakan tugasnya. Selain itu perlu juga pembinaan budi pekerti (akhlak) melalui berbagai kesempatan seperti ceamah-ceramah agama.

\section{Pemberdayaan Wakaf Secara Produktif sebagai Upaya meningkatkan Kesejahteraan Umat}

Kesadaran masyarakat untuk mengamalkan tingkat religiusitasnya dengan cara wakaf memang cukup tinggi. Namun sayangnya, banyak aset wakaf yang tingkat pendayagunaannya stagnan, dan tidak sedikit yang tidak berkembang sama sekali. Penyebabnya banyak sekali, di antaranya sebagaimana yang telah disebutkan di atas. Oleh karena itu, pilihan menganut manajemen modern dalam pengelolaan harta wakaf menjadi keniscayaan dan keharusan untuk secepatnya dilakukan.

Prinsip pengelolaan aset wakaf adalah pengembangan secara produktif agar dapat meningkatkan ekonomi dan kesejahteraan masyarakat. Sebab, substansi atau ruh dari ajaran wakaf adalah produktifitas. Produktifitas inilah yang nantinya secara langsung ataupun tidak akan berdampak pada peningkatan ekonomi ummat. Jika aset wakaf tidak diproduktifkan, maka nilai ibadah sosial yang dapat mengalirkan manfaat abadi akan menghilang.

Dalam rangka untuk mengembangkan dan mengoptimalkan harta wakaf secara produktif, terdapat 2 (dua) model pembiayaan proyek wakaf produktif, yaitu secara tradisonal dan institusional.

\section{Secara tradisional}

Dalam model pembiayaan harta wakaf secara tradisional sebagaimana terdapat dalam kitab fikih klasik terdapat lima model pembiayaan rekonstruksi harta wakaf, yaitu $^{32}$ (a) Pembiayaan wakaf dengan menciptakan wakaf baru untuk melengkapi harta wakaf yang lama, jenis pembiayaan dengan menambah harta wakaf baru pada harta wakaf yang lama ini sudah lama ada dalam sejarah Islam, seperti pada masjid, sekolah, rumah sakit, panti asuhan, universitas, dan kuburan dan lain-lain. (b) Pinjaman untuk pembiayaan kebutuhan operasional harta wakaf dan pemeliharaan untuk mengembalikan fungsi wakaf sebagaimana mestinya. (c) Penukaran pengganti (substitusi) harta wakaf, dalam hal ini paling tidak memberikan pelayanan atau pendapatan yang sama tanpa perubahan peruntukan yang ditetapkan waqïf. (d) Pembiayaan hukr. ${ }^{33}$ Hal ini untuk mensiasati larangan menjual harta wakaf. Dari pada menjual harta wakaf, nadir dapat menjual hak untuk jangka waktu sewa dengan suatu nilai nominal secara periodik. (e) Pembiayaan ijaratain (sewa dengan dua kali pembayaran). Di sini ada dua bagian, yaitu: pertama, berupa uang muka lump sum yang besar untuk merekonstruksikan harta wakaf yang bersangkutan, dan kedua, berupa sewa tahunan secara periodik selama masa sewa.

2. Secara institusional

Dalam rangka mengembangkan wakaf secara produktif, terdapat beberapa model pembiayaan yang membolehkan pengelola wakaf produktif memegang hak eksklusif terhadap pengelolaan, di mana naḍir dalam hal ini dapat bermitra dengan bank syariah. Jadi, posisi bank syariah dalam memanfaatkan aset wakaf untuk usaha produktif bukan

\footnotetext{
32 Pedoman Pengelolaan dan Pengembangan Wakaf Depag RI Tahun 2006, 114-118.

${ }^{33}$ Sewa berjangka panjang dengan lump sum pembayaran di muka yang besar.
} 
sebagai naḍir, tapi mitra nadirir. Kemitraan ini diharapkan dapat menjembatani kondisi nadir yang masih tradisional agar mampu mengelola dan mengembangkan aset wakaf secara produktif. ${ }^{34}$ Tentu saja, arah kemitraan ini tak hanya dalam soal penerimaan dan menyalurkan wakaf uang, tapi juga dalam pengembangan aset wakaf, baik tanah maupun uang.

Untuk dapat mengimplementasikan kemitraan antara bank syariah dan naḍir wakaf dalam mengembangkan usaha produktif, terdapat bentuk-bentuk alternatif akad yang dapat dilakukan, yaitu: ${ }^{35}$

a. Muräbaḥah, adalah perjanjian jual-beli antara bank dengan nasabah, di mana bank syariah membeli barang yang diperlukan nasabah kemudian menjualnya kepada nasabah yang bersangkutan sebesar harga perolehan ditambah dengan margin keuntungan yang disepakati antara bank syariah dan nasabah. Dalam hal ini, naḍir memposisikan dirinya sebagai pengusaha pengendali proses investasi, yang membeli berbagai keperluan proyek wakaf, seperti material, peralatan dan lain-lain kepada bank. Adapun pembayarannya akan dibayar kemudian (diangsur) diambilkan dari pendapatan hasil pengembangan wakaf. Model ini lebih tepat dilakukan dalam pengembangan aset wakaf berupa tanah atau bangunan.

Skema 1.1 Pembiayaan Murābạ̣ah

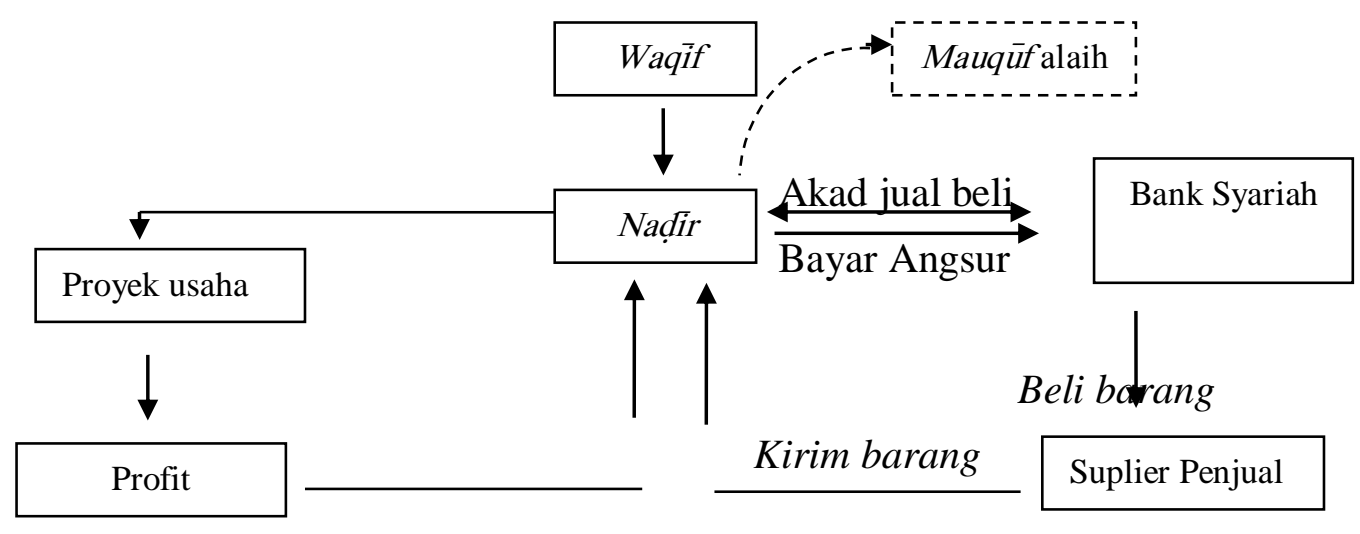

b. Istișna', adalah jual beli barang dalam bentuk pemesanan, pembuatan barang dengan kriteria dan persyaratan tertentu yang disepakati dengan pembayaran sesuai dengan kesepakatan. Model istișna' dalam pemberdayaan wakaf tidak jauh berbeda dengan model murābahah, hanya saja akadnya bukan jual beli, tapi pemesanan barang. Naḍir memesan barang kepada bank, misalnya bahan material bangunan untuk membangun rumah sakit. Setelah itu, pembayaran dilakukan secara berkala, dari hasil keuntungan pengelolaan. Desain ini cocok untuk pengembangan aset berupa tanah atau bangunan.

\footnotetext{
${ }^{34}$ UU No. 41 Tahun 2004 tentang Wakaf Pasal 43 ayat (2) dan penjelasannya.

35 Ibid., 119.
} 
Skema 1.2 Pembiayaan Istịnña'

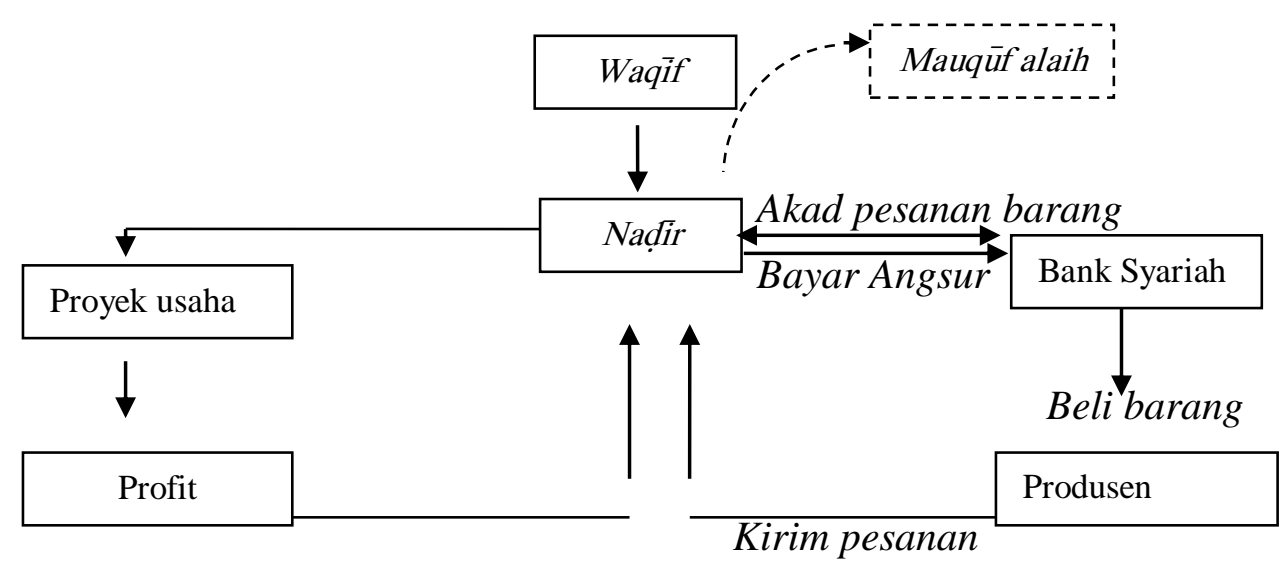

c. Model ijärah muntahiyah bi al-tamlik (financial leasing with purchase option), yaitu sewa yang diakhiri dengan pemindahan kepemilikan barang, sejenis perpaduan antara kontrak jual beli dan sewa atau lebih tepatnya akad sewa yang diakhiri dengan kepemilikan barang di tangan penyewa. Dalam hal ini nad̦ir memegang kendali penuh atas menajemen proyek. Naḍir memberikan izin berjangka kepada penyedia dana untuk mendirikan sebuah gedung di atas tanah wakaf. Naḍir menyewa gedung tersebut untuk jangka waktu yang sama. Nadir menjalankan menajemen dan membayar sewa secara periodik kepada penyedia dana. Ini lebih tepat digunakan dalam pengembangan aset tanah wakaf untuk properti. Jumlah sewa telah ditetapkan sehingga menutup modal pokok dan keuntungan yang dikehendaki penyedia dana.

Skema 1.3 Pembiayaan Ijarah Muntahiyah Bittamlik

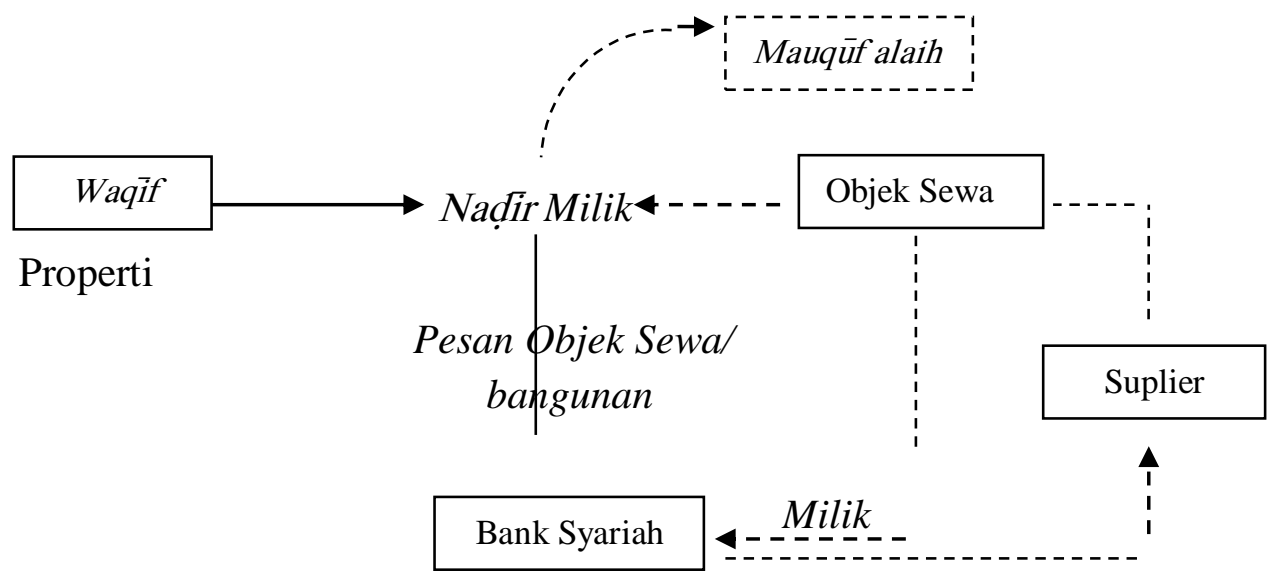

d. Model muzāra'ah adalah kerja sama pengolahan pertanian antara pemilik lahan dengan penggarap di mana pemilik lahan memberikan lahan pertanian kepada si penggarap untuk ditanami dan dipelihara dengan imbalan bagian tertentu (persentase) dari hasil panen. Kerjasama model di mana naḍir menyediakan segala hal yang terkait dengan pengelolaan, mulai dari lahan, benih, pupuk, dan sebagainya. Naḍir bekerjasama dengan pihak kedua sebagai pengelola, dengan imbalan 
persentase dari hasil panen. Naḍir memfungsikan tanah wakaf sebagai lahan pertanian/agribisnis.

Skema 1.4 Pembiayaan Model Muzara'ah

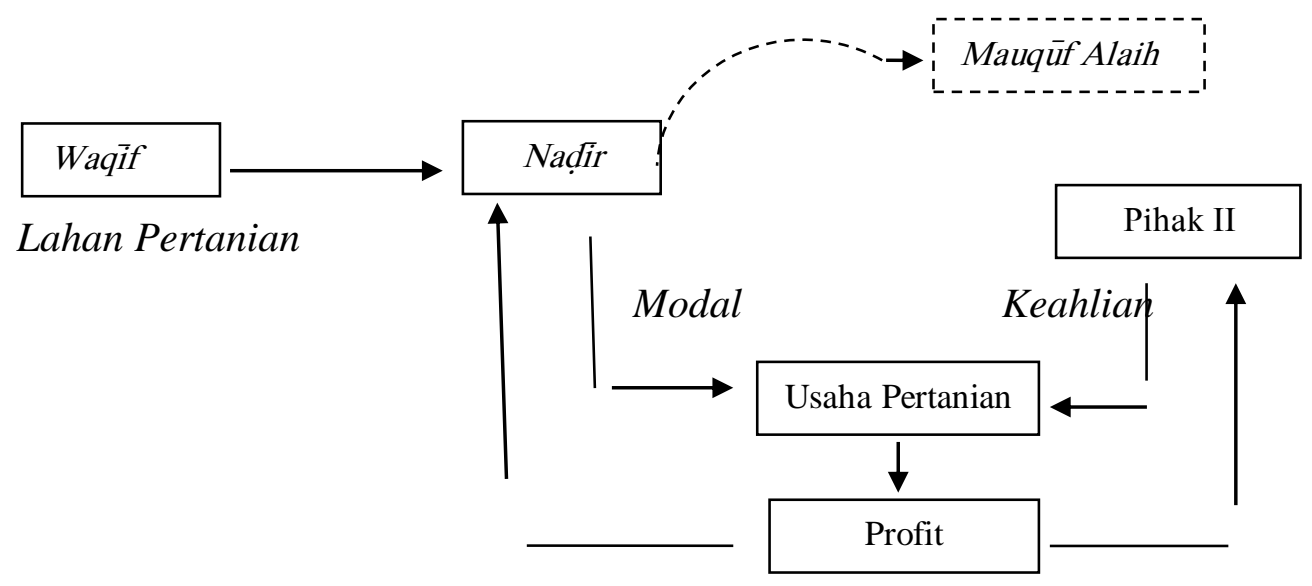

e. Model qard hasan merupakan pinjaman dana kepada nasabah tanpa imbalan dengan hanya mengembalikan pokok pinjaman secara sekaligus atau cicilan dalam jangka waktu tertentu. Al-Qarḍ al-ḥasan ditujukan bagi orang yang tidak mampu (fakir dan/atau miskin) untuk modal usaha yang berkelanjutan. Baik uang ataupun tanah dapat dikembangkan dengan model ini. Dalam praktiknya, hampir sama dengan mushārakah atau muḍ̄ărabah. Hanya saja, tidak ada bagi hasil keuntungan. $100 \%$ keuntungan menjadi hak milik naḍir.

Skema 1.5 Pembiayaan Model Qarḍ Hasan

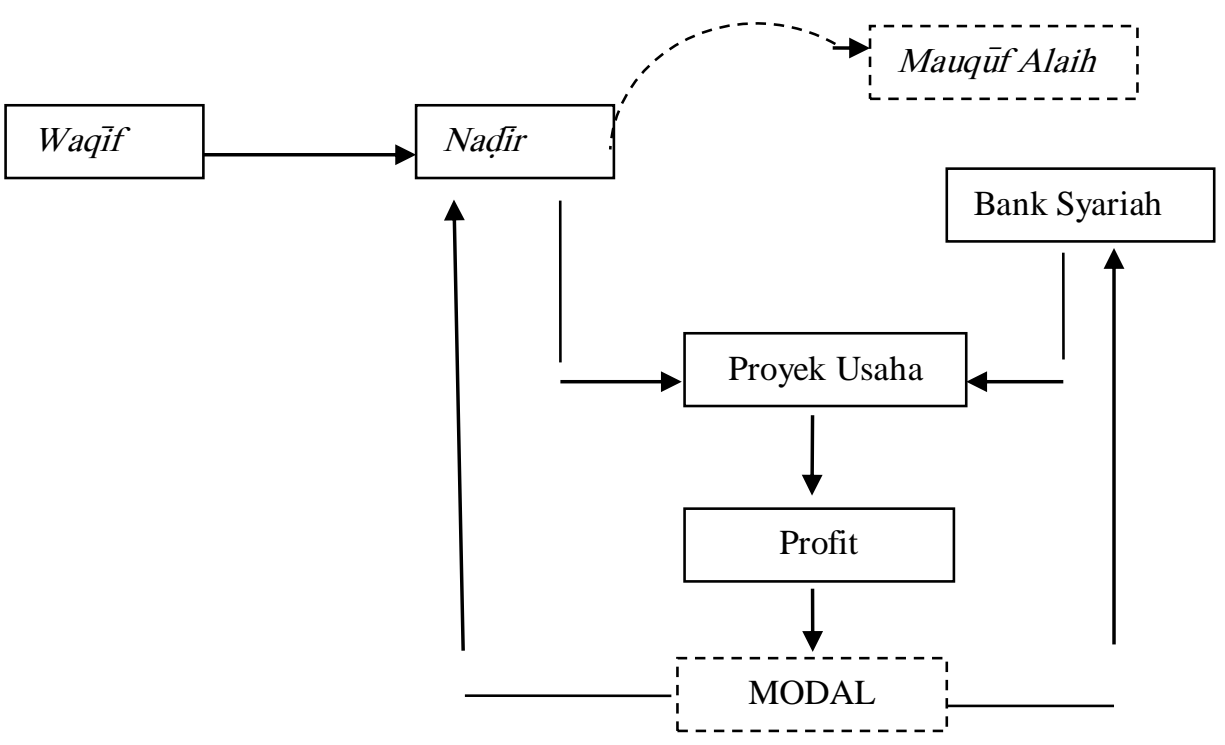

f. Model mushārakah (partnership) adalah akad kerja sama antara dua pihak atau lebih untuk suatu usaha tertentu di mana masing-masing pihak memberikan kontribusi dana (atau amal/expertise) dengan kesepakatan bahwa keuntungan dan resiko akan ditanggung bersama sesuai dengan kesepakatan. Ini juga cocok dalam 
pengembangan jenis aset wakaf berupa uang atau tanah. Langkah praktisnya, nadir bisa melalui bank, atau dapat pula langsung bekerjasama dengan pihak kedua dan ketiga tanpa melalui bank. Masing-masing pihak berkontribusi pada modal.

Skema 1.6 Pembiayaan Mushārakah

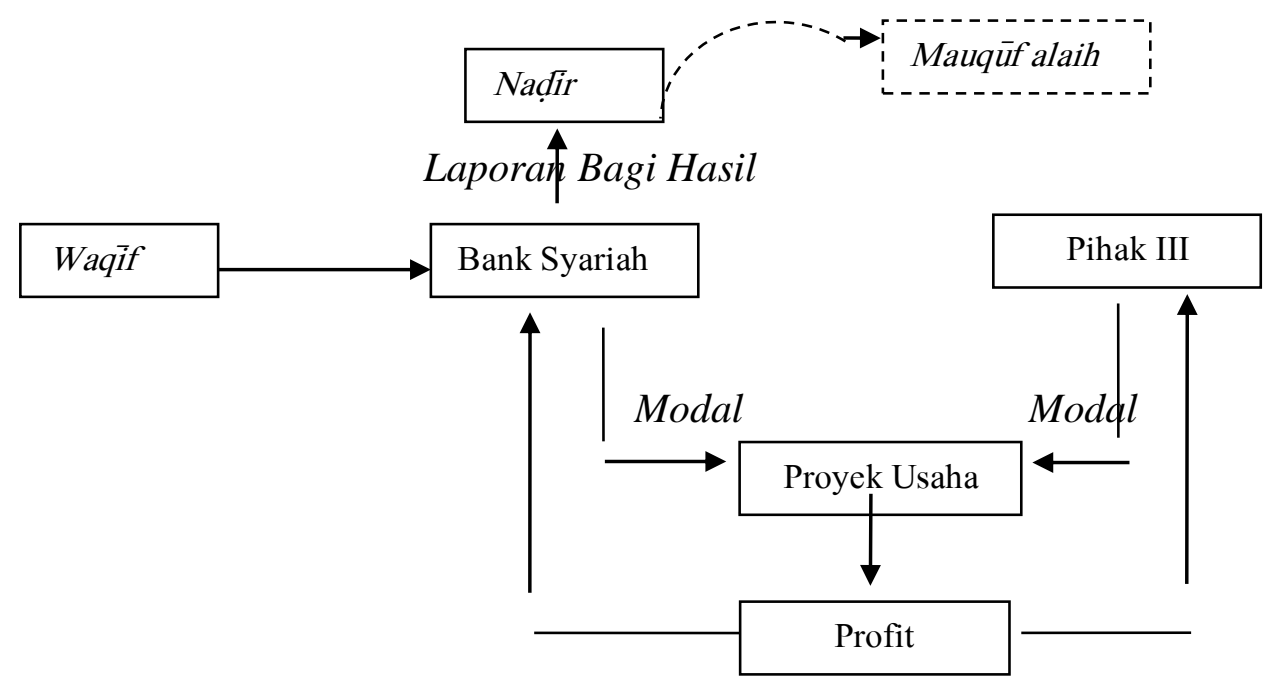

g. Model muḍārabah muqayyadah, yaitu akad kerjasama antara șăhỉb al-māl (penyedia dana) dengan mudạarib (pengelola) yang disertai pembatasan penggunaan dana dari șăhib al-māl untuk investasi-investasi tertentu. Model ini bisa digunakan untuk pengembangan wakaf uang ataupun tanah. Waqif melalui nadir atau dapat langsung menyetorkan wakaf uang ke bank. Bank lalu bekerjasama dengan pihak ketiga dalam suatu proyek. Bank sebagai șạhib al-māl, pihak krtiga sebagai muḍārib. Pengembangan aset wakaf model ini dapat dilakukan langsung oleh naḍir, tanpa melalui bank.

Skema 1.7 Pembiayaan Muḍārabah Muqayyadah

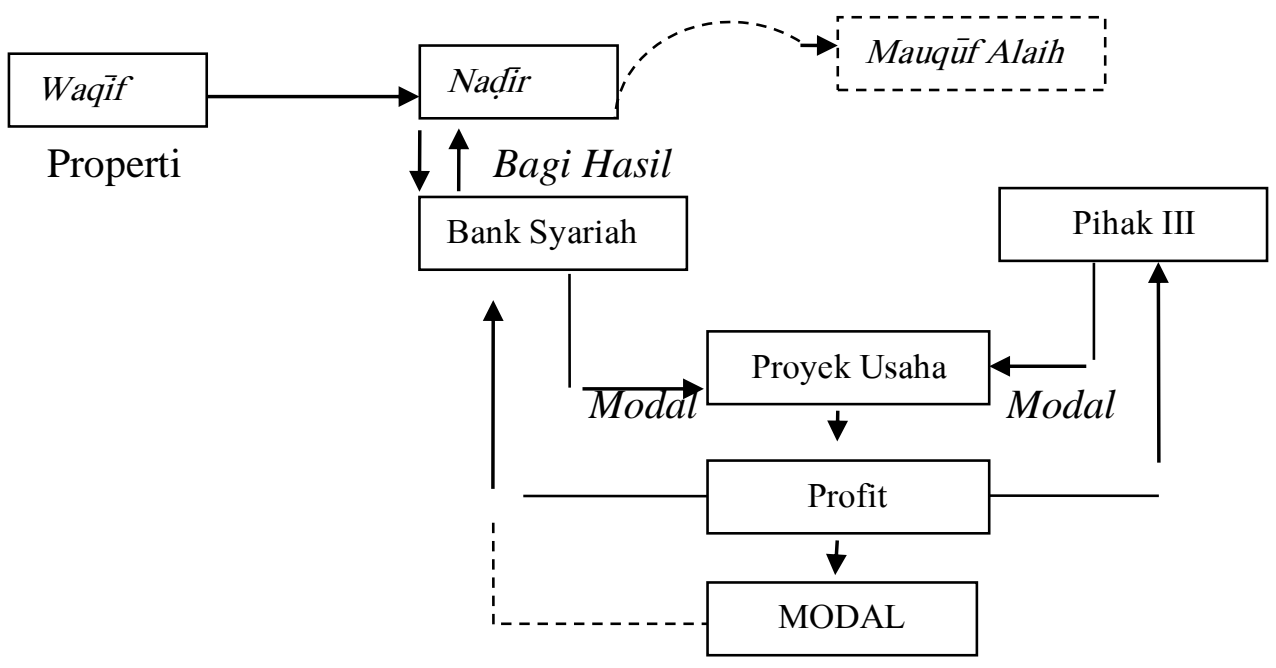


Upaya untuk memproduktifkan harta wakaf dengan beberapa akad di atas dengan menggandeng bank syariah, ada beberapa manfaat yang dapat diperoleh kedua belah pihak, bank syariah dan naḍir wakaf. Bagi bank syariah, kemitraan ini membawa beberapa manfaat. Pertama, meningkatnya eksistensi lembaga perbankan syariah. Dengan adanya sosialisasi wakaf kepada masyarakat, secara tidak langsung juga merupakan langkah sosialisasi lembaga perbankan. Kedua, jika dana yang dihimpun oleh bank bertambah banyak, maka akan memperbesar pula perolehan pendapatan bagi bank syariah. Ketiga, memberikan citra positif kepada lembaga perbankan syariah, karena bank syariah menyalurkan dananya untuk pembiayaan di sektor riil, sehingga jaringan lembaga perbankan yang tersebar luas.

Sementara dari sisi nadir, pertama, naḍir dapat memanfaatkan kemampuan lembaga perbankan dalam investasi, baik jangka pendek, menengah, maupun panjang. Pertimbangan jenis investasi apa yang lebih menguntungkan dan sedikit resiko perlu diketahui oleh nadir. Hal ini tentu dapat dilakukan jika nadir bermitra dengan bank syariah. Kedua, naḍir terhindar dari resiko ketidakprofesionalan. Dalam pembangunan proyek atau investasi dibutuhkan administrasi yang rapi. Naḍir selaku pihak yang diberikan kepercayaan oleh waqif dalam pengelolaan harta wakaf harus mampu mengadministrasikan semua transaksi yang dilakukan. Dengan bantuan bank syariah, naḍir akan mampu mengemban amanah waqïf dengan baik. Ketiga, kredibilitas naḍir di mata masyarakat akan meningkat, sebab dalam kerjanya, naḍir tidak hanya dapat menjaga harta wakaf, tetapi diapun mampu menjadikan harta wakaf berkembang. Keempat, kemitraan ini dapat dijadikan proses pembelajaran bagi naḍir menuju kualitas naḍir profesional. Melalui kemitraan yang bersifat produktifit inilah yang nantinya secara langsung ataupun tidak, akan berdampak pada meningkatnya kesejahteraan ummat, sehingga problema kemiskinan dapat terminimalisasi.

\section{Kesimpulan}

Wakaf di samping sebagai akad tabarru' yang berorientasi ibadah, wakaf juga merupakan economic corporation, di mana wakaf merupakan kegiatan yang mengandung unsur investasi masa depan untuk generasi yang akan datang baik berupa pelayanan maupun pemanfaatan hasilnya secara langsung. Fungsi dan peran wakaf sangat besar dalam menopang perkembangan dan kemajuan umat Islam, oleh karena itu pengelolaan wakaf harus mampu dioptimalkan. Tragisnya pengelolaan wakaf di Indonesia sampai saat ini masih kurang maksimal, sehingga ada beberapa harta wakaf yang terlantar dalam pengelolaannya, bahkan ada yang hilang. Hal tersebut disebabkan di antaranya manajemen pengelolaan wakaf masih menggunakan pola manajemen tradisional-konsumtif.

Upaya untuk mengembangkan wakaf agar beperan dan berfungsi secara produktif, terdapat 4 hal yang harus diperhatikan, yaitu aspek kelembagaan, aspek akuntansi, aspek auditing dan aspek naḍir. Jika keempat aspek tersebut dapat terpenuhi, maka pemanfaatan wakaf akan lebih berdaya guna. Ada beberapa bentuk model yang dapat dijalankan oleh pengelola wakaf, di antaranya dengan menggandeng banks syariah sebagai mitra. Model murābaḥah, istiṣnā', model ijārah muntahiyah bi al-tamlik (financial leasing with purchase option), muzāra'ah, qarḍ ḥasan, mushārakah (partnership) dan muḍārabah muqayyadah. 


\section{Daftar Rujukan}

al-Asqalāni, Ibn Hajar. Fatḥ al-Bāri. Kairo: Mușṭafā al-Ḥalabi, 1959.

al-Dāsūqì, Muḥammad Shams al-Dīn. Hạshiyah al-Dāsūqù 'alā al-Sharh al-Kabìr, juz 2. Beirut: Dār al-Fikr, t.th.

al-Munawar, Said Agil Husain. Hukum Islam dan Pluralitas Sosial. Jakarta: Penamadani, 2004.

al-Nawawi, Abū Zakariya Yahyā ibn Sharaf. Sahịịh Muslim bi Sharh al-Nawawi. Beirut: Dār al-Fikr, 1983.

al-Ramli, Ibn Shihāb. Nihāyah al-Muhtāàj, Juz IV. Beirut: Dār al-Kitāb al-Alamiyah, t.th.

al-Ṣan'ani, Muḥammad Ismaìl Āmir al-Yamani. Subul al-Salām. Kairo: Muṣtafāa al-Bāb alHalabi, 1349 H.

al-Sharbini. Muhạmmad al-Khāțib, Mughnī al-Muhtāj, juz 2. Kairo: Muṣțafā al-Bāb alHalabi, 1958.

Anonim. Paradigma Baru Wakaf di Indonesia. Jakarta: Direktorat Pemberdayaan Wakaf Departemen Agama, 2007.

Anonim. Pedoman Pengelolaan dan Pengembangan Wakaf. Jakarta: Bimas Direktorat Pemberdayaan Wakaf Departemen Agama RI, 2006.

Arens, Alvins A. Auditing I, terj. Amir Abadi Yusuf. Jakarta: Ikrar Mandiri Abadi, 1997.

Departemen Agama RI. Ilmu Fiqh, Jilid III. Jakarta: Ditjen Binbagais, 1986.

Djuneidi, Achmad. Menuju Era Wakaf Produktif. Jakarta: Mumtaz Publishing, 2008.

Fikri, Sayyid Ali. al-Mu'āmalāt al-Mādiyah wa al-Adabiyah, Juz II. Mesir: Muștafā al-Bāb al-Halaby, t.th.

Ibn Manzūr. Lisān al-'Arab, Jld. 11. Kairo: al-Dār al-Miṣriyyah li al-Ta' Tif wa al-Tarjamah, 1954.

Ibn Qudāmah, al-Mughnī. Beirut: Dār al-Fikr, 1994.

Imam Muslim. Șahịḥ Muslim, Juz II. Bandung: PT Al-Ma'arif, t.th.

Manan, Abdul. Sertifikat Wakaf Tunai, Sebuah Inovasi Instrumen Keuangan Islam. Jakarta: Ciber-PKTTI-UI, 2001.

Cash Waqf Certificate- an Innovation in Islamic Financial Instrument: Global Opportunities for Developing Social Capital Market in the $21^{\text {st }}$ Century Voluntary Sector Banking. Cambridge: Harvard University, 1999.

Najib, dkk. Wakaf, Tuhan, dan Agenda Kemanusiaan. t.t.p: t.p., 2006.

Nasution, Mustafa Edwin, dkk. Pencanangan Gerakan Nasional Wakaf Uang oleh Presiden RI. Jakarta: Badan Wakaf Indonesia, 2010.

"Peranan Badan Wakaf Indonesia dalam Pengembangan Wakaf di Indonesia" dalam Jurnal al-Awqaf, Vol. 1, No. 1 tahun 2008.

Rofiq, Ahmad. Hukum Islam di Indonesia. Jakarta: PT Grafindo Persada, t.th.

Sabiq, Sayyid. Fiqh al-Sunnah. Beirut: Dar al-Fikr, 1992.

Soemita, Andri. Bank \& Lembaga Keuangan Syariah, cet ke-2. Jakarta: Kencana, 2010.

Undang-Undang Nomor 41 Tahun 2004. 